\title{
DEMONSTRATION OF ANTIBODY AND CELLULAR IMMUNE RESPONSE TO BRAIN EXTRACT IN WEST AND LENNOX-GASTAUT SYNDROMES
}

\author{
NORMA G. S. MOTA* \\ M. THEREZA REZKALLAH-IWASSO * \\ M. TEREZINHA S. PERACOLI * \\ TEREZINHA C. .B. MONTELLI
}

It is proposed that West syndrome could be the result of a non-specific reaction of immature brains to different kinds of insults and brain damages. This affirmation, however, is only an obvious account, not an explanation 3 . The possible relationship between hypsarrhytmia and demyelinating conditions, post viral illness or immunization has been suggested by Gordon 5. Although the allergic nature of West syndrome cannot be accepted as established, the empiric ACTH therapy may lead to full recovery or prevent severe brain damage. Very few immunological papers have been done in the field of child neurology. In 1963, Reinskov 19 has demonstrated the presence of a precipitating antibody to extract of brain tissues in four children with West syndrome. Recently, we have studied the immune status of five patients with this disorder and found some alterations of the cellular immune response, with several degrees of immunodeficiency 14. Depressed $\mathrm{T}$ lymphocyte function has been described in association to several autoimmune disorders $7,17,21$. However, the exact interrelationship among the abnormalities in the immune function and the autoimmune phenomenon remains to be elucidated.

In this context, the present work was carried out in order to investigate humoral and cellular immune response to brain tissues, in children with West syndrome and its related condidion, the Lennox-Gastaut syndrome.

\section{MATERIAL AND METHODS}

The test group consisted of 24 children, aged between 4 months and 18 years, whose clinical and eletroencephalographic (EFG) features allowed the diagnosis of West and Lennox-Gastaut syndromes. Twenty healthy children, 12 male and 8 female (age range, 6 months to 8 years) formed the control group. Remarkable clinical characteristics and EEG alterations at the moment of immunological evaluation are detailed in table 1.

Department of Microbiology and Immunology (*) and Department of Neurology (**), IBBMA - UNESP. Acknowledgements - The authors wish to thank Dr. Florence Kerr Correa for manuscript revision and Mr. Irineu Machado for technical assistance. 
Case Sex Age L O EEG Presumptive etiology

Remarkable clinical and/or neurological features

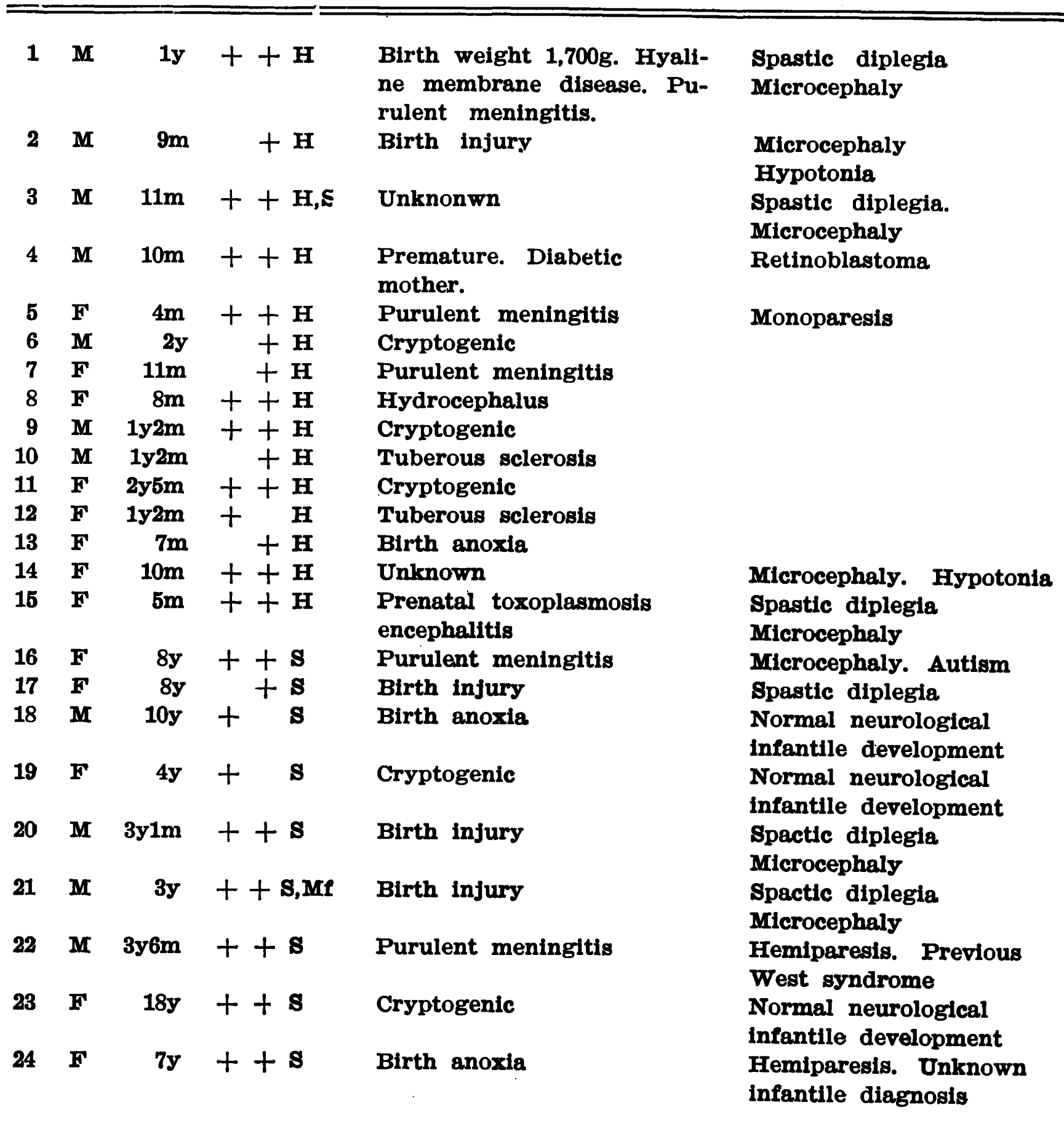

Table 1 - Data of cases with Wcst cond Lennox-Gastaut syndromes: M, masculin; $F$, feminin; $y$, years; $m$, months; $H$, hypsarrhytmia; 8 , generalized sharp and slovo-vave complexes; Mf, multifocal. Tests with brain antigen: $L$, leucocyte mignation inhibition; o, Ouchterlony immunodiffusion.

Neurological evaluation - EEG were recorded on a Flema Shoenander instrument, using the 10-20 international system of electrode placement and both bipolar and unipolar derivations. Records were obtained during spontaneous or barbituric induced sleep. Urine qualitative tests for inborn metabolic errors were performed in every children (clinistix, fenistix, clinitest, 2-4 dinitrophenylhydrazine and azure A). Antigen - A crude antigen was prepared from normal brain tissue obtained from 
one brain traumatized patient during surgery. The brain tissue was cold homogenized In a Virtis homogenizer in $0.15 \mathrm{M}$ sodium dihydrogen phosphate buffered saline (PBS) adjusted to $\mathrm{pH} 7.2$ with $1 \mathrm{M}$ sodium hydroxide and centrifuged at $600 \mathrm{~g}$ for 30 minutes. The supernatant was filtered through a $0.22 \mu \mathrm{m}$ Millipore and submitted to sterility tests. Antigen protein content was determined according to the method of Lowry et al 13. The agar-gel immunodiffusion test (ID) - Was performed according to Ouchterlony16 employing 1 percent Ionagar in sodium veronal buffer with lonicity 0.05 and $\mathrm{pH}$ 8.6. Brain antigen was used at the concentration of $4 \mathrm{mg} / \mathrm{ml}$. Sera studied by ID were previously absorbed with human erythrocytes and then tested in successive dilutions of ratio 2 up to 1:640. Inhibition of peripheral leucocyte migration (LMI) - The method of Mota et al 15 with minor modifications was employed for LMI studies. Blood was taken in twenty units of preservative-free heparin/ml and allowed to sediment at $37^{\circ} \mathrm{C}$. The leucocite-rich plasma was withdrawn and centrifuged at $200 \mathrm{~g}$ for 10 minutes. The pellet was washed twice in PBS and the cells resuspended in Eagle's medium (Gibco, Grand Island, Co.) containing 10 percent horse serum, at $5 \times 107$ leucocytes/ml. A polyethylene capillary tube was filled with the leucocyte suspension, cut into $5 \mathrm{~cm}$ lenght segments and sealed at one end with wax. The capillary tubes were centrifuged at $150 \mathrm{~g}$ for 5 minutes, cut at cell-fluid interface, and two capillaries per culture chamber were mounted on silicone dabs. Control chambers contained only Engle's medium with 10 percent horse serum, while the test chambers received, in addition, brain antigen at a concentration of 200 and $400 \mu \mathrm{g}$ of protein $/ \mathrm{ml}$. Culture chambers were sealed with a coverslip and incubated for 18 hours at $37^{\circ} \mathrm{C}$. After incubation, the surface area of migration was measured microscopically using an eyepiece quadriculated graticule. The results were expressed as "migration index" with the ratio: (mean area of migration with antigen: mean area of migration without antigen) $\times 100$.

\section{RESULTS}

Table 2 shows the distribution of anti-brain antibodies in the groups studied. Titers higher than 1:40 were detected in all patients. On Ouchterlony immunodiffusion plates of controls, West and Lennox Gastaut patients, there was everytimes one line of identity.

\begin{tabular}{lcccc}
\hline Groups & No & Negative & $\begin{array}{c}\text { Positive } \\
1 / 1-1 / 10\end{array}$ & $\begin{array}{c}\text { Positive } \\
1 / 40-1 / 160\end{array}$ \\
\hline Lennox-Gastaut & 20 & 9 & 11 & 0 \\
West & 14 & 0 & 0 & 14 \\
Control & 7 & 0 & 0 & 7 \\
\hline
\end{tabular}

Table 2 - Antibody titers to brain tissue in normal children, and West and Lennox-Gastaut patients.

The individual leucocyte migration indices for the subjects tested with brain antigen are presented in Figure 1. The difference observed between patient and control groups, at a concentration of 200 and $400 \mu \mathrm{g}$ of protein $/ \mathrm{ml}$, was statistically significant. 


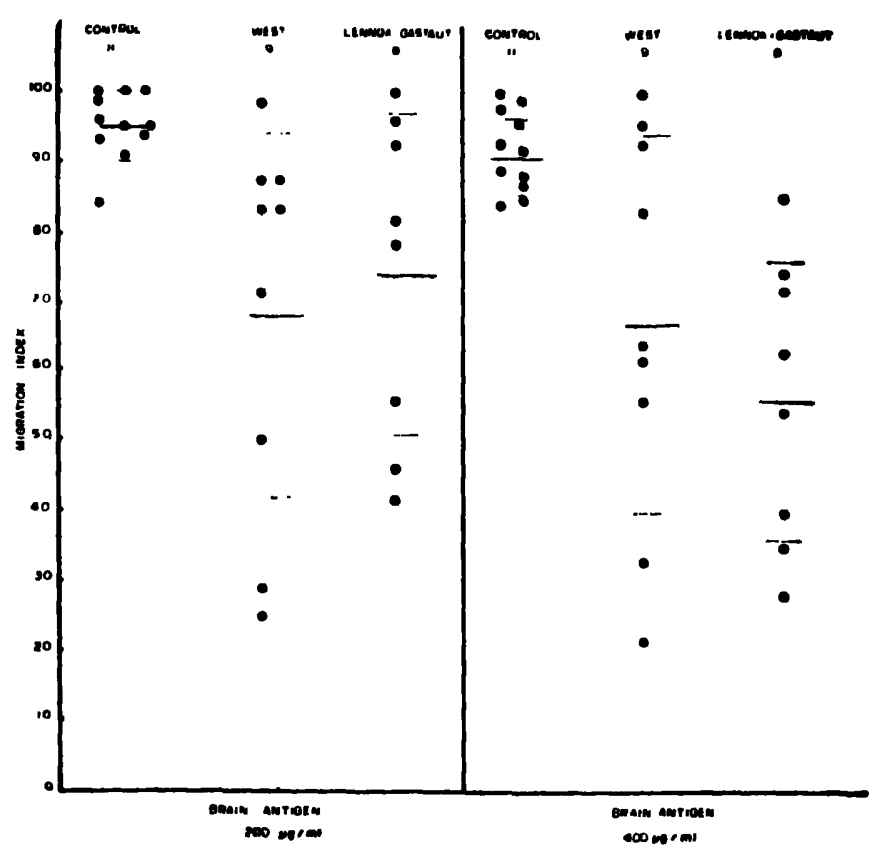

Fig. 1 - Leucocyte migration index with brain antigen in patients with West and Lennox-Gastaut syndromes and healthy controls. Horizontal bars represent mean \pm SD. Statistical analysis by Mann-Whitney U test. (Control $x$ West, Ag $200 \mu g) p<0.025$; (Control $x$ West, $A g 400 \mu g) p<0.05$; (Control $x$ Lennox, $A g 200 \mu g$ ) $p<0.025$; (Contol $x$ Lennox, Ag $400 \mu g$ ) $p<0.001$; (Lennox $x$ West) not significant.

\section{DISCUSSION}

All children studied with progressive epileptic encephalopathy showed high levels of a precipitating antibody to a saline extract of brain tissue. Low antibody titers detected in normal children may be accounted for by interference from histocompatibility antigens or autoimmune phenomenon with regulatory or physiologic function 6 . No strict correlation was found between antibody levels and clinical status of patients, such as cryptogenic or secondary forms of illness, age of onset, frequençy and types of epileptic episodes, insults and causes of brain damage. Whether the autoantibody production represents a primary pathogenic mechanism of these diseases or a secondary response to the release of brain antigen is unknown. In clinical medicine there are numerous examples of autoantibody production without autoimmune disease 18,21. Such responses are not always harmful 17 and in some circunstances may be positively beneficial, playing an important role in regulating the immune response 8.

Leucocyte migration inhibition test with brain antigen was found to be positive in a high proportion of patients with West and Lennox-Gastaut syndromes. To our knowledge, this is the first time that specifically sensitized lymphocytes to brain tissue were detected in patients with these neurological diseases. In previous work ${ }^{14}$ we have detected variable degrees of cellular immunodeficiency in five patients with West syndrome. Several authors have reported that autoimmune diseases comprise an array of disorders of the immune system 2, 12,17,20. Evidence has been presented suggesting that a reduction in supressor cell activity might be implicated in the pathogenesis of autoimmune diseases 0,21 . The cellular auto-sensitization observed in patients with West and Lennox-Gastaut syndromes might be considered either as an epiphenomenon not directly involved in the pathogenesis of these syndromes or as playing important causative role in these diseases. 
Most types of epilepsy are associated with tissue damage. It is proposed by Ettlinger and Lowrie ${ }^{4}$ that epileptic discharges could be the result of an autoimmune response triggered by exposure to antigen during brain destruction of various kinds or by an infectious agent. These authors have suggested that a possible mechanism involves the blocking by antibodies of inhibitory synapses. In this context, the effect of ACTH therapy in West and LennoxGastaut syndromes may be due either to an immunosuppressive action 22 or to a reduction of vascular permeability. Experimental reports have shown that is possible to produce epileptiform activity using an immunoneurological model. Epileptic discharges were obtained after cortical or subdural injection of antisera to synaptic membrane fraction and to brain gangliosides 10,11. Similar effects were observed by Bowen et al ${ }^{1}$ using topical application of antiserum to brain actomyosin-like protein. Further studies are needed to elucidate the pathogenic processes involved in West and Lennox-Gastaut syndromes. Relevant aspects such as the relation of autoimmune response with illness onset, children development and neurological outcome should be investigated. In addition, it is necessary to study the permeability of blood-brain barrier and to characterize the antigenic fraction present in the brain extract and to study the specificity of the antibody.

\section{SUMMARY}

We investigated humoral and cellular immune response to brain tissues in 15 patients with West syndrome, in 9 patients with Lennox-Gastaut syndrome and in 20 healthy children. High levels of a precipitating antibody to a saline extract of brain tissue were detected in all patients; leucocyte migration inhibition test with the same antigen was found to be positive in most of them. The role of this autoimmune response in the pathogenesis of West and Lennox-Gastaut syndromes remains to the elucidated.

\section{RESUMO}

Demonstração de anticorpos e resposta imune celular a extrato de cérebro nas sindromes de West e Lennox-Gastaut

Investigamos a resposta imunológica celular e humoral frente a extrato salino de tecido cerebral em 9 pacientes com síndrome de Lennox-Gastaut, 15 pacientes com síndrome de West e 20 crianças normais. A técnica de imunodifusão dupla em gel de agar (Ouchterlony) evidenciou em todos os pacientes, altos níveis de um anticorpo precipitante contra o extrato salino de tecido cerebral. $O$ teste de inibição de migração de leucócitos com o mesmo antígeno mostrou-se positivo na maioria dos pacientes. $O$ possível papel destas respostas autoimmunes na patogenia das sindromes de West e Lennox-Gastaut é discutido. 


\section{REFERENCIAS}

1. BOWEN, F. P.; Kosarova, J.; CASEllla, D.; NICKLAS, W. \& BERL, S. Focal epileptogenic activity induced by topical application of antisera to brain actomyosin-like protein. Brain. Res. 102:363, 1976.

2. CANTOR, H.; McVAY-BROUDREAU, L.; HUNGENBERG, J.; NAIDORF, $K$.; SHEN, F. W. \& GERSHON, R. K. - Immunoregulatory circuits among $T$ cell sets. II. Physiologic role of feedback inhibition in vivo: absence in NZB mice. J. exp. Med. 147:1116, 1978.

3. Chevrie, J. J. - Syndrome de West. Encicl. Méd. Chir. Neurologie, 17045 A80:5. Paris, 1979.

4. ETTLINGER, G. \& LOWRIE, M. B. - An immunological factor in epilepsy. Lancet 1:1386, 1976.

5. GORDON, N. - Long-term prognosis after infantile spasms. Develop. Med. Child. Neurol. 23:260, 1981.

6. GRABAR, P. - Hypothesis: auto-antibodies and immunological theories: an analytical review. Clin. Immunol. Immunopathol. 4:453, 1975.

7. HANDWEGER, B. S.; FERNANDES, G. \& BROWN, D. M. - Immune and autoimune aspects of diabetes mellitus. Human Pathol. 11:338, 1980.

8. JERNE, N. K. - The immune system. Sci. amer. 229:52, 1973.

9. KAPP, J. A.; PIERCE, C. W.; THEZE, J. \& BENACERRAF, B. - Modulation of immune response by supressor $T$ cells. Fed. Proc. 37:2361, 1978.

10. KARPIAK, S. E.; GRAF, L. \& RAPPORT, M. M. - Antiserum to brain gangliosides produces recurrent epileptiform activity. Science 194:735, 1976.

11. KARPIAK, S. E.; SEROKOSZ, M. \& RAPPORT, M. M. - Effects of antisera to S-100 protein and to synaptic membrane fraction on mice performance and EEG. Brain Res. 102:313, 1976.

12. LANDO, Z.; TEITELBAUM, D. \& ARNON, R. - Effect of cyclophosphamide on supressor cell activity in mice unresponsive to EAE. J. Immunol. 123:2156, 1979.

13. LOWRY, O. H.; ROSENBROUGH, N. J.; FARR, A. L. \& RANDALL, R. J. Protein measurement with the phenol reagent. J. biol. Chem. 193:265, 1951.

14. MONTELLI, T. C. B.; IWASSO, M. T. R.; PERACOLI, M. T. S. \& MOTA, N. G. S. - Cell mediated and humoral immunity in West Syndrome. Arq. Neuro-Psiquiat. (São Paulo) 39:1, 1981.

15. MOTA, N. G. S.; KIY, Y.; REZKALLAH-IWASSO, M. T. \& PERACOLI, M. T. S. - Humoral and cell-mediated immunity in large non-toxic multidodular goitre. Clin. Endocrinol. 13:173, 1980.

16. OUCHTERLONY, O. - Antigen-antibody reaction in gels. Acta pathol. microbiol. scand. 29:507, 1949.

17. REES, A. J. - Autoimmunity and autoimmune disease. Brit. J. Anaesthesiol. 51: 13, 1979.

18. REES, A. J.; LOCKWOOD, C. M. \& PETERS, D. K. - Nephritis due to antibodies to glomerular basement membrane. In: P. Kincold-Smith \& A. J. F. d'Apice (eds.) - Progress in glomerulonephritis. John Wiley, New York, 1978.

19. REINSKOV, T. - Demonstration of precipitating antibody to extract of brain tissue in patients with hypsarrhytmia. Acta Paediat. suppl. 140:73, 1963.

20. SHOENFELD, Y.; PICK, A. I.; DANZIER, Y.; KALACZI, I.; FROLICHMAN, R. \& PINKHAS, J. - Immunoglobulin changes in SLE. Ann. Allergy 39:99, 1977.

21. TALAL, N.; ROUBINIAN, J. R.; SHEAR, H.; HOM, J. T. \& MIYASAKA, N. Progress in the mechanims of autoimmune disease. Prog. Immunol. IV:889, 1980.

22. TOURTELOTTE, W. W.; BAUNMHEFNER, R. W.; POTVIN, A. R.; MA, B. I.; POTVIN, J. H.; MENDEZ, M. \& SYNDULKO, $\mathbf{K}$ - Multiple sclerosis de novo CNS IgG synthesis: effect of ACTH and corticosteroids. Neurology (Minneapolis) 30:1155, 1980. 